\title{
Solitary glandular papilloma of the peripheral lung: a report of two cases
}

Kaoru Kaseda ${ }^{1,3^{*}}$, Hirotoshi Horio ${ }^{1}$, Masahiko Harada ${ }^{1}$ and Tsunekazu Hishima ${ }^{2}$

\begin{abstract}
Solitary papilloma of the lung is thought to be a rare benign epithelial tumor, and complete surgical resection is currently the standard treatment for this pathology. However, some cases of papilloma have reportedly shown malignant potential. We report two cases of solitary glandular papilloma of the peripheral lung that were treated by thoracoscopic partial resection. The first patient presented with a nodular lesion in the lower lobe of the left lung that was detected on a follow-up chest computed tomography (CT) scan after treatment for laryngeal cancer. Partial lung resection was performed by video-assisted thoracoscopic surgery. In the second patient, a nodular lesion was incidentally identified in the lower lobe of the left lung during a health check-up. Partial lung resection was again performed by video-assisted thoracoscopic surgery. The postoperative course in both cases was uneventful, and no recurrences have been observed as of 44 months and 41 months postoperatively, respectively. To the best of our knowledge, malignant transformation has been reported both with the squamous type and the mixed type of solitary papilloma of the lung. The glandular variant has shown no tendency toward local recurrence after local excision and has no apparent malignant potential. Local excision is thus recommended for solitary glandular papilloma in order to preserve pulmonary function.
\end{abstract}

Keywords: Solitary papilloma, Glandular papilloma, Surgical resection

\section{Background}

Solitary pulmonary papilloma is a rare neoplasm that is usually derived from bronchial surface epithelium and forms an endobronchial tumor [1-3]. Solitary pulmonary papillomas are subclassified into three categories according to histological type: squamous cell papilloma, glandular papilloma, and mixed squamous cell and glandular papilloma (mixed papilloma) [2]. Of these, glandular papilloma of the peripheral lung is uncommon, with only 20 cases reported in the English literature [2,4-7]. The clinicopathologic features thus remain unclear. Here we report two cases of solitary glandular papilloma of the peripheral lung, and discuss the clinical implications of surgery for this.

\footnotetext{
* Correspondence: kaseda@wb4.so-net.ne.jp

'Department of Thoracic Surgery, Tokyo Metropolitan Cancer and Infectious Diseases Center Komagome Hospital, 3-18-22, Honkomagome Bunkyo-ku, Tokyo 113-8677, Japan

${ }^{3}$ Department of Thoracic Surgery, Sagamihara Kyodo Hospital, Kanagawa, Japan

Full list of author information is available at the end of the article
}

\section{Case presentation \\ Case 1}

In January 2010, a 64-year-old man with a smoking history of two packs of cigarettes daily for 40 years was noted to have an abnormal lesion in the left lung on chest computed tomography (CT) performed as follow-up after treatment for laryngeal cancer. He was therefore referred to our department. The previous laryngeal cancer had shown complete clinical response after chemoradiotherapy and the patient had no respiratory symptoms. Laboratory data were unremarkable, and serum tumor marker levels were all within normal limits. Chest CT revealed a solitary pulmonary nodule $0.8 \times 0.8 \mathrm{~cm}$ in size in segment 9 of the left lung (Figure 1a). In August 2010, the patient underwent partial resection of the left lower lobe of the lung by video-assisted thoracoscopic surgery (VATS) for treatment and diagnosis. Intraoperative pathological examination using frozen sections suggested inflammatory granuloma without malignant features. Postoperative histological examination demonstrated that the tumor was comprised of a fibrovascular core and papillomatous fronds lined by pseudostratified columnar epithelium (Figure 1b). The columnar epithelium 

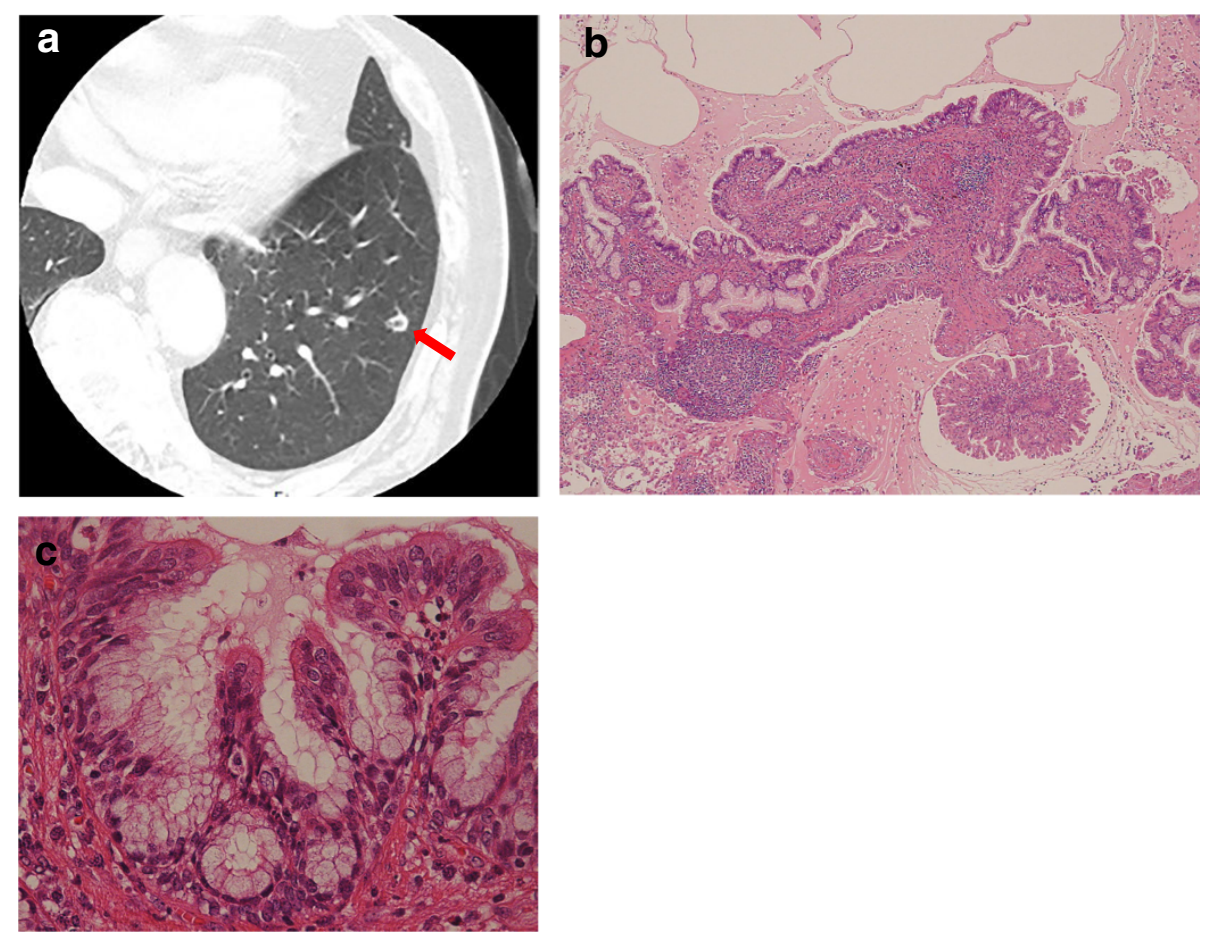

Figure 1 Imaging and pathological findings in Case 1. a) Chest computed tomography (CT) shows a $0.8 \times 0.8$-cm nodule in segment 9 of the left lung (arrow). b) Low-power histologic view of the resected tumor (hematoxylin-eosin staining). The tumor consists of a fibrovascular core and papillomatous fronds lined by pseudostratified columnar epithelium. c) High-power view of b (hematoxylin-eosin staining). The columnar epithelium consists of ciliated columnar cells, goblet cells and basal cells with no cytologic or architectural atypia.

consisted of ciliated columnar cells, goblet cells and basal cells with no cytologic or architectural atypia (Figure 1c). On the basis of these morphological findings, glandular papilloma of the lung was diagnosed. As of 44 months postoperatively, the patient remains clinically and radiographically disease-free.

\section{Case 2}

In August 2010, a 73-year-old woman with no smoking history was noted to have an abnormal lesion in the left lung during a health check-up and was thus referred to our department. She had no relevant past history and no respiratory symptoms. Laboratory data were unremarkable, and serum levels of tumor markers were all within normal limits. Chest CT revealed a solitary pulmonary nodule with air and solid components $1.0 \times 0.8 \mathrm{~cm}$ in size in segment 9 of the left lung (Figure 2a). In November 2010, the patient underwent VATS partial resection of the lower lobe of the left lung for treatment and diagnosis. Intraoperative pathological examination using frozen sections suggested glandular papilloma of the lung. Postoperative histological examination showed the tumor was comprised of a fibrovascular core and papillomatous fronds lined by pseudostratified columnar epithelium (Figure 2b). The pseudostratified columnar epithelium consisted of ciliated columnar cells and numerous mucous cells with no cytologic or architectural atypia (Figure 2c). As of 41 months postoperatively, the patient remains clinically and radiographically disease-free.

\section{Conclusions}

Pulmonary papillomas can be classified according to the number of lesions, location or histology [2]. With regard to the number of lesions, pulmonary papillomas are divided into two types, multiple and solitary. Multiple papillomas, representing papillomatosis, are usually related to infection with papillomavirus, most often occurring in children and young adults, and involving both the upper and lower respiratory tracts. Solitary papillomas are rarer and predominantly affect adults [8-11]. According to location, pulmonary papillomas can be classified as central endobronchial or peripheral bronchiolar types. Flieder et al. reviewed 14 cases of solitary pulmonary papillomas, describing 13 as central endobronchial papillomas and only 1 as $a$ peripheral bronchiolar papilloma [2]. The majority of peripheral bronchiolar papillomas are small, asymptomatic and only discovered incidentally on chest radiography, as in both our cases. In contrast, $a$ central endobronchial 

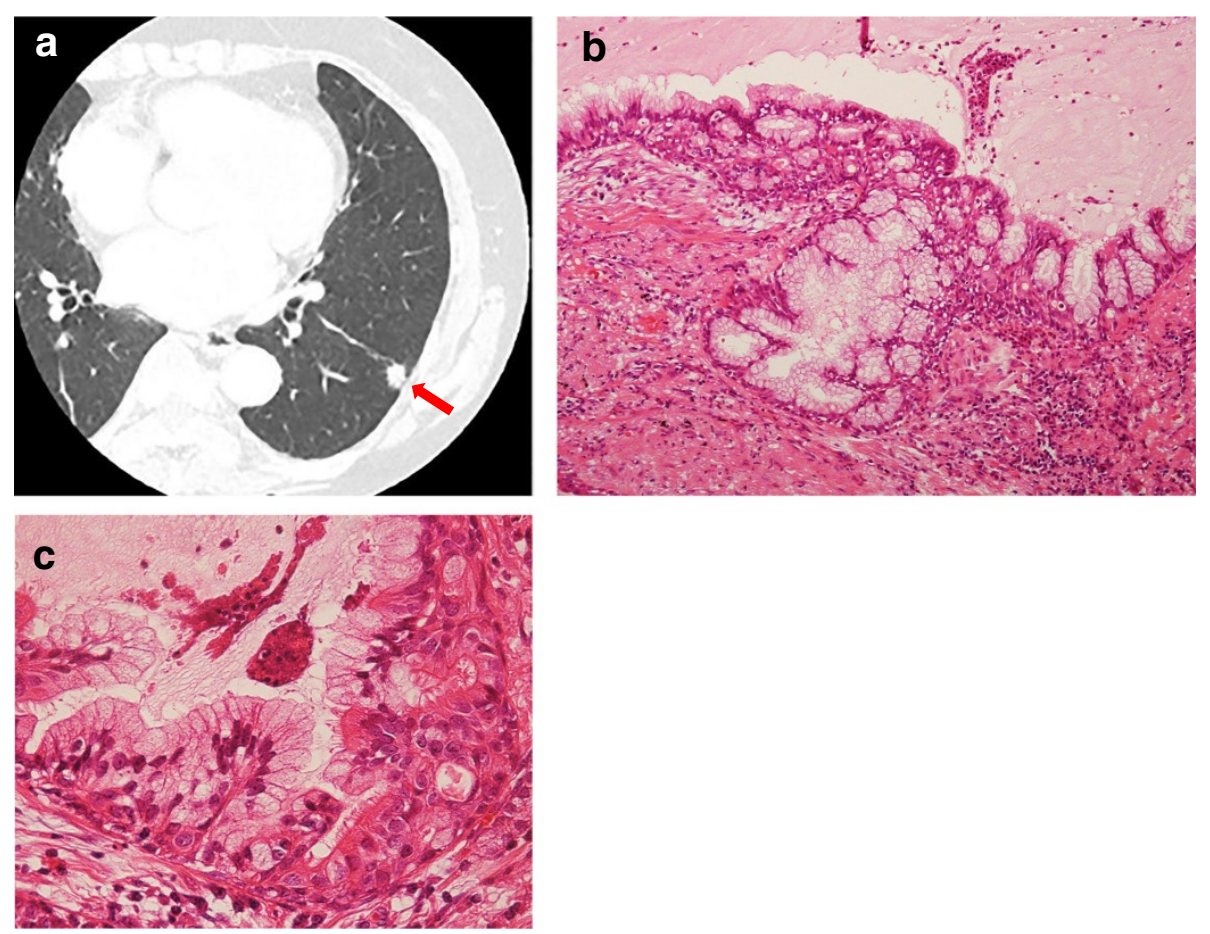

Figure 2 Imaging and pathological findings in Case 2. a) Chest computed tomography (CT) shows a $1.0 \times 0.8$-cm nodule in segment 9 of the left lung (arrowhead). b) Low-power histologic view of the resected tumor (hematoxylin-eosin staining). The tumor is composed of a fibrovascular core and papillomatous fronds lined by pseudostratified columnar epithelium. c) High-power view of b (hematoxylin-eosin staining). The pseudostratified columnar epithelium consists of ciliated columnar cells and numerous mucous cells, with no cytologic or architectural atypia.

papilloma often causes $a$ persistent, paroxysmal and/or productive cough. Screening for lung cancer using chest radiography has recently gained popularity among healthy people in Japan, so opportunities to discover asymptomatic peripheral papillomas may increase. Pulmonary papillomas are histologically divided into three categories: squamous cell, glandular and mixed types [2,12]. Squamous cell papillomas are the most common. Glandular papillomas of the peripheral lung seem to be rare, with only 20 cases reported to date in the English literature [2,4-7]. Peripheral bronchiolar papillomas sometimes grow along alveolar walls and display an appearance similar to peripheral adenocarcinomas of the bronchioloalveolar or papillary type. For differential diagnosis, it is noteworthy that endobronchiolar papillomatous fronds are constantly present and spread along the alveolar walls is limited in alveoli adjacent to peripheral papillomas. The presence of ciliated cells and basal cells is considered an important finding for confirming the diagnosis [4].

In both of our cases, the patient was successfully treated by local excision. To the best of our knowledge, malignant transformation has only been reported with the squamous variant [13]. The glandular variant does not appear to recur locally after local excision and has no proven malignant potential. We therefore recommend local excision for solitary glandular papilloma.

\section{Consent}

Written informed consent was obtained from the patient for the publication of this case presentation and accompanying images. A copy of the written consent is available for the review by the Editor-in-Chief of this journal.

\section{Abbreviations}

CT: Computed tomography; VATS: Video-assisted thoracoscopic surgery.

\section{Competing interests}

The authors declare that they have no competing interests.

\section{Authors' contributions}

$\mathrm{KK}$ and $\mathrm{HH}$ wrote the manuscript. $\mathrm{KK}, \mathrm{HH}$ and $\mathrm{MH}$ performed the surgery. TH carried out the pathological examination. All authors approved the final manuscript.

\section{Author details}

'Department of Thoracic Surgery, Tokyo Metropolitan Cancer and Infectious Diseases Center Komagome Hospital, 3-18-22, Honkomagome Bunkyo-ku, Tokyo 113-8677, Japan. ${ }^{2}$ Department of Pathology, Tokyo Metropolitan Cancer and Infectious Diseases Center Komagome Hospital, Tokyo, Japan. ${ }^{3}$ Department of Thoracic Surgery, Sagamihara Kyodo Hospital, Kanagawa, Japan.

Received: 11 April 2014 Accepted: 6 May 2014

Published: 19 May 2014 


\section{References}

1. Basheda S, Gephardt GN, Stoller JK: Columnar papilloma of the bronchus: case report and literature review. Am Rev Respir Dis 1991, 144:1400-1402.

2. Flieder DB, Koss MN, Nicholson A, Sesterhenn IA, Petras RE, Travis WD: Solitary pulmonary papillomas in adults: a clinicopathologic and in situ hybridization study of 14 cases combined with 27 cases in the literature. Am J Surg Pathol 1998, 22:1328-1342.

3. Spencer $\mathrm{H}$, Dail DH, Arneaud J: Non-invasive bronchial epithelial papillary tumors. Cancer 1980, 45:1486-1497.

4. Aida S, Ohara I, Shimazaki H, Dai Y, Ogata S, Ozeki Y, Tamai S: Solitary peripheral ciliated glandular papillomas of the lung: a report of 3 cases. Am J Surg Pathol 2008, 32:1489-1494.

5. Nakagawa M, Hara M, Shibamoto Y, Yano M, Takahashi S: CT findings of bronchial glandular papilloma. J Thorac Imaging 2008, 23:210-212.

6. Emerson $L L$, Layfield $\mathrm{L}$ : Solitary peripheral pulmonary papilloma evaluation on frozen section: a potential pitfall for the pathologist. Pathol Res Pract 2012, 208:726-729.

7. Tryfon S, Dramba V, Zoglopitis F, lakovidis D, Sakkas L, Kontakiotis T, Galanis $\mathrm{N}$ : Solitary papillomas of the lower airways: epidemiological, clinical, and therapeutic data during a 22-year period and review of the literature. J Thorac Oncol 2012, 7:643-648.

8. Barzo P, Molnar L, Minik K: Bronchial papillomas of various origins. Chest 1987, 92:132-136.

9. Drennan JM, Douglas AC: Solitary papilloma of a bronchus. J Clin Pathol 1965, 18:401-402.

10. Maxwell RJ, Gibbons JR, O'Hara MD: Solitary squamous papilloma of the bronchus. Thorax 1985, 40:68-71.

11. Roviaro GC, Varoli F, Pagnini CA: Is the solitary papilloma of the bronchus always a benign tumor? ORL J Otorhinolaryngol Relat Spec 1981, 43:301-308.

12. Flieder DB, Thivolet-Bejui F, Popper H: Papilloma. In Pathology and Genetics of Tumours of the Lung, Pleura, Thymus and Heart. Lyon, France: IARC Press; 2004:78-81.

13. Inoue $\mathrm{Y}$, Oka M, Ishii H, Kimino K, Kishikawa M, Ito M, Ito T, Nakashima M, Kohno S: A solitary bronchial papilloma with malignant changes. Intern Med 2001, 40:56-60.

doi:10.1186/1477-7819-12-149

Cite this article as: Kaseda et al: Solitary glandular papilloma of the peripheral lung: a report of two cases. World Journal of Surgical Oncology 2014 12:149.

\section{Submit your next manuscript to BioMed Central and take full advantage of:}

- Convenient online submission

- Thorough peer review

- No space constraints or color figure charges

- Immediate publication on acceptance

- Inclusion in PubMed, CAS, Scopus and Google Scholar

- Research which is freely available for redistribution 